\title{
Imagem jornalística e representações sociais: a imagem dos Sertões
}

\author{
Juliana Andrade Leitão* \\ Maria Salett Tauk Santos**
}

\begin{abstract}
Resumo
Este estudo tem o objetivo de analisar as representações sociais que a imprensa de circulação nacional faz dos Sertões do Nordeste nas reportagens de alcance nacional. A pesquisa está fundamentada na teoria das Representações Sociais, imagem fotográfica e jornalismo. Trata-se de um estudo de caso que analisa as imagens fotográficas disponíveis pela agência Globo e o jornal O Globo em seu portal online de notícias. São analisadas as temáticas, títulos e subtítulos de todas as fotografias disponíveis no site, correspondentes ao tema Sertão no período de 2003 a 2010. O estudo evidenciou que as imagens denotam uma representação do Sertão como local de isolamento, de seca, miséria, sem acesso a tecnologia, a saneamento, com sistema precário de transporte e rudimentares práticas agrícolas. Palavras chave: Representações sociais. Mídia. Sertão. Nordeste. Foto-Jornalismo.
\end{abstract}

\section{Photojournalism and social representations: the image of the Brazilian 'Sertões'}

\section{Abstract}

The current study aims to analyzes the social representations made by the national press about the "sertões" (hinterlands) in northern Brazil. The research

\footnotetext{
* Doutoranda do Programa de Pós-Graduação em Comunicação Social, Centro de Artes de Comunicação, Faculdade da Universidade Federal de Pernambuco (UFPE) - Recife, PE, Brasil. Professora do curso de Publicidade e Propaganda da Escola Superior de Marketing e da Faculdade Joaquim Nabuco. Mestre em Extensão Rural e Desenvolvimento Local pela Universidade Federal Rural de Pernambuco - POSMEX/ UFRPE. Jornalista, E-mail: julleitao@gmail.com.

** Professora do Programa de Pós-Graduação em Extensão Rural e Desenvolvimento Local (Posmex), Departamento de Educação, Universidade Federal Rural de Pernambuco, Recife, PE, Brasil. Doutora em Ciências da Comunicação pela Universidade de São Paulo. Coordenadora do GT Comunicação, Tecnologia e Culturas Populares do Posmex/UFRPE e do GP Comunicação e Desenvolvimento Regional e Local da Intercom. E-mail: mstauk@hotmail.com.
} 
focus is centered on photographs published by newspapers, therefore, identifying elements that take place on people's mind due to the those published stories that introduce the Sertão to the rest of Brazil. It is a case study to analyze photographs, available from Agência Globo and O Globo newspaper website, related to Sertão between 2003 and 2010. The case study presents evidence that those images led to a representation of Sertão as a place of isolation, dry, poverty, with no access to technology and sanitation, with a very poor structure of transportation and farming.

Key words: Social representations. Press. Hinterlands. Northeast. Media. Photojournalism.

\section{Imagen periodística y representaciones sociales: la imagen de lós 'Sertões' brasileños \\ Resumen}

Este estudio tiene como objetivo analizar las representaciones sociales que la prensa de circulación nacional se utiliza para representar los Sertões del Noreste de Brasil en los reportages de alcance nacional. La investigación está fundamentada en la teoría de las Representaciones Sociales, imagen fotográfica y periodismo. Se Trata de un estudio de caso que analiza las imágenes fotográficas disponibles por la agencia de noticias Globo y el periódico O Globo en su portal online de noticias. Son analizadas las temáticas, títulos y subtítulos de todas las fotografías disponibles en su página web, correspondientes al tema Sertão entre 2003 y 2010. El estudio mostró que las imágenes denotan una representación del Sertão como lugar de aislamiento, seca, miseria, sin acceso a tecnología, saneamiento, con sistema precario de transporte y prácticas agrícolas rudimentales. Palavras clave: Representaciones sociales. Imprensa. Sertão. Noreste. fotoperiodismo.

\section{Introdução}

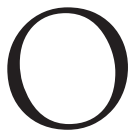

objetivo deste artigo é analisar as representações sociais que a imprensa de circulação nacional faz dos Sertões do Nordeste nas reportagens de alcance nacional. As questões que norteiam o estudo estão centradas na forma como são veiculadas as matérias de vários jornais de alcance nacional, que historicamente retratam o Sertão, reduzindo-o à seca, à presença de caveiras e da terra rachada. A argumentação para a escolha do tema se fundamenta na forma como tem sido estigmatizada a Região, seus costumes e sua população no senso comum com simbolismos e mitos, reforçados pelo discurso midiático. 
A mídia muitas vezes tem contribuído para perpetuar esse modelo estagnado de pensamento e percepção sobre o que acontece nas regiões do Nordeste, principalmente no Sertão. Parece que em muitos casos existe certo descompasso entre o que acontece de mudanças efetivas em algumas regiões do país e o que é representado, que muitas vezes mostra-se a partir de formatos pré-estabelecidos de imagens caricatas, reforçando estereótipos de pessoas esquálidas, locais aparentemente abandonados e isolados e parece nunca considerar o Sertão que possui Universidade Federal Rural, pesquisa agropecuária e tecnologias na produção e exportação de frutas seguindo padrões internacionais de cultivo e armazenamento, além de internet, arte de projeção nacional etc. Ao invés disso o que aparece é o sertanejo que ratifica a imagem dos "Retirantes", de Portinari, reducionismo que pode contribuir para a diminuição de investimentos na região.

O Norte e o Nordeste são vistos como as regiões rurais que parecem ter parado no período colonial, são abordadas como cidades folclóricas, alegres, cheias de luz e arquitetura barroca e o Sul e Sudeste como as regiões urbanas moderna, rica, movimentada, multicolorida, polifônica e cheia de luminosidades contemporâneas (ALBUQUERQUE JÚNIOR, 2001 p.104-105).

Essas delimitações conceituais existentes no senso comum limitam as possibilidades do termo rural e do termo urbano. É precisamente por conta do contraste entre o que é o rural hoje e como ele é representado na mídia por meio das imagens que a pesquisa se faz relevante para quem trabalha com jornalismo, para que esse debate proporcione uma autocrítica sobre escolhas feitas, linha editorial entre outros.

Pensando na forma reducionista que muitas vezes o Sertão aparece representado nos meios de comunicação de massa, nas possibilidades jornalísticas ainda pouco exploradas sobre aspectos de desenvolvimento econômico, social e cultural dessa rica região e do que tem aparecido na mídia, se chegou ao seguinte questionamento:

De que formas a imprensa de alcance nacional reforça a imagem do Sertão como local desprovido de riquezas e sujeito somente à seca? 
A importância do conhecimento que será gerado com esta pesquisa consiste na observação de representações socialmente enraizadas na sociedade brasileira no que diz respeito ao Nordeste, ao povo nordestino e especificamente ao Sertão e ao povo sertanejo. A representação do Nordeste precisa ser questionada e reavaliada por aqueles que se colocam como vozes que falam para o Brasil sobre este Brasil, que muitas vezes desconhecem. Essa atitude e a forma de fazer jornalismo têm reforçado preconceitos consolidados no país até hoje. Um exemplo desse preconceito é a Comunidade no Orkut "Eu odeio Nordestinos".

\section{A pesquisa}

Trata-se de um estudo de caso, que instrumentaliza a análise das representações sociais que a imprensa de circulação nacional faz dos sertões do Nordeste nas reportagens especiais disponibilizadas no site do jornal $\mathrm{O}$ Globo.

Iniciou-se com uma pesquisa piloto na qual foram coletados dados sobre o tema nos jornais: Folha de S.Paulo, O Estado de S.Paulo e $O$ Globo e o website de noticias UOL. A opção pela coleta de dados da internet se deve ao crescimento exacerbado do meio de informação online, por se constituir numa fonte de pesquisa cada vez mais comum, para a modalidade de pesquisa exploratória e facilidade de acesso às matérias de jornais de outros estados. Os sites selecionados pertencem a grupos de comunicação jornalística. Assim, chegou-se aos seguintes resultados sobre o tema Sertão: O Globo mostrou 931 resultados, Jornal O Estado de S.Paulo 1.309 notícias, Folha de S.Paulo 3.178 resultados e UOL 86.986.

Devido ao número fez-se um recorte considerando as matérias especiais, matérias com foto e fotogaleria (galeria de imagens agrupadas correspondentes a um mesmo assunto). Todas as fotografias acima mencionadas foram vistas e observadas atentamente para fazer posteriormente uma decisão criteriosa de recorte metodológico para esta pesquisa. Esse levantamento demandou um processo de dois meses. A justificativa para a escolha do website de notícias do jornal O Globo, deve-se ao fato 
de ser um jornal que possui repórter e fotógrafos a serviço desse veículo aqui em Pernambuco, por disponibilizar uma quantidade grande de imagens em fotogalerias sobre os diversos assuntos e organização do referido site. São analisadas as temáticas, títulos e subtítulos de todas as fotografias disponíveis no portal, depois de observar as fotogalerias que $O$ Globo disponibiliza, que datam do período de 2003 a 2010 e que sejam de cunho jornalístico.

As fundamentações teóricas em Representações Sociais combinadas com teorias do jornalismo e da imagem deram base para a construção das categorias de análise:

1. Arquétipos de pessoas, objetos, vegetação (considera as imagens do Sertão vindas de relatos, do imaginário coletivo).

2. Recorte espaço-temporal (época e localização das imagens)

3. Técnicas fotográficas (enquadramento, recorte, foco, cores e horário da luz).

4. A notícia mostrada pela imagem (título, a legenda texto que de alguma forma traga informações sobre a fotografia).

Coisas que não são classificadas e que não possuem nomes são estranhas, não existentes e ao mesmo tempo ameaçadoras (MOSCOVICI, 2009), observa-se então como um olhar sobre o Sertão representado torna-se senso comum tendo a participação dos meios de comunicação nesse processo rotulando, categorizando e encaixando de forma reducionista uma multiplicidade de informações imagéticas que o Sertão oferece. Como as Representações Sociais observam que a sociedade estabelece categorias para explicar um tema, pensou-se em criar categorias a partir do que as imagens mostram para ver que senso comum está impregnado na mídia e consequentemente na sociedade sobre a região.

\section{Imagem e representação Social}

A pesquisa está fundamentada na teoria das Representações Sociais, imagem fotográfica e desenvolvimento local. Da teoria 
das Representações Sociais utilizou-se, fundamentalmente, Serge Moscovici e Celso Pereira de Sá, deste último ressaltamos a importância das manifestações culturais ou matérias veiculadas pela mídia como fonte de dados (SÁ, 1998, p.58). O autor explica também que as Representações circulam por meio da difusão: "típica da imprensa de grande circulação" (SÁ, 1996, p.35). De Moscovici (2009) consideramos a importância dada às convenções, cultura, a memória social e histórica no processo de ancoragem (classificar, rotular e categorizar). O segundo conceito trazido é o da objetivação, ou seja, "produzir um conceito em uma imagem" (MOSCOVICI, 2009, p.72).

Nesta pesquisa, a fotografia de imprensa consiste num recorte metodológico para análise da representação na mídia. "A fotografia de imprensa é uma mensagem" (BARTHES, 2009, p.11). Utiliza-se este autor que discute quem produz quem escolhe e como esta imagem comunica com os textos aos quais faz referência, como título, legenda e até mesmo o nome do jornal: "A estrutura da fotografia não é uma estrutura isolada; comunica, pelo menos, com uma outra estrutura, que é o texto (título, legenda ou artigo) que acompanha toda a fotografia de imprensa" (BARTHES, 2009, p.12). O autor $(2009$, p.21) ao falar de texto e imagem diz que:

[...] o texto constitui uma mensagem parasita, destinada a conotar a imagem, isto é, a "insuflar-lhe" um ou vários segundos significados. Por outras palavras, e é uma inversão histórica importante, a imagem já não ilustra a palavra; é a palavra que, estruturalmente, é parasita da imagem.

Os textos que acompanham as galerias tornaram-se importantes fontes de análise dentro desta pesquisa, pois auxiliam na compreensão do que o jornal quer comunicar com aquela determinada imagem e que precisa ser levada em consideração, o autor chega a dizer que a legenda "pela sua própria disposição, pela sua medida de leitura, parece duplicar a imagem, isto é, participar na sua denotação" (BARTHES, 2009, p.22). No capítulo "A Retórica da Imagem", Barthes (2009, p.33) explica 
que a imagem tem como característica principal o fato de ser polissêmica, devemos, então, sempre buscar informações que auxiliem na sua compreensão.

Para compreender as possíveis leituras que se fazem de uma imagem é importante levar em consideração os dois componentes principais da imagem (KOSSOY, 1999) que podem ser de ordem material (recursos técnicos, óticos e eletrônicos) e de ordem imaterial (mentais e culturais).

Outro aspecto importante para quem estuda imagem e que é recorrente em vários autores é o da memória. O que Pesavento chama de "arquivo de memória" ou "museu imaginário" que todo homem carrega, e que abarca o visto, o sabido, o lido, o adquirido, o ouvido (PESAVENTO, 2008, p.101), as imagens que o espectador vê comunica com aquelas imagens guardadas na memória. Aumont (1994) fala que ao ver uma imagem a memória é ativada. Assim muitas das imagens sobre o Sertão que vemos nas galerias trazem uma lembrança cultural de outras fontes que falaram sobre o Sertão como é o caso das descrições de Euclides da Cunha ou dos quadros de Portinari, havendo assim uma rememoração de uma realidade construída socialmente.

Outro aspecto considerado são os múltiplos pontos de vista: "vemos, hoje, que o estudo da imagem é fundamental para o entendimento dos múltiplos pontos de vista que os homens constroem a respeito de si mesmos e dos outros" (ALEGRE, 1998, p.76).

Aumont traz a importância do recorte ou enquadramento. Esse processo que ele chama mental e material "pelo qual se chega a uma imagem que contém determinado campo visto sob determinado ângulo e com determinados limites exatos" (AUMONT, 1994, p.153). Nesse sentido, a fotografia irá mostrar o ponto de vista daquele lugar ou situação do fotógrafo: "lugar onde uma coisa deve ser colocada para ser bem vista" (AUMONT, 1994, p.156). O ponto de vista do fotógrafo será percebido pelo leitor da imagem: 
1. Um local, real ou imaginário, a partir do qual uma cena é olhada; 2. O modo particular como uma questão pode ser considerada; 3. Enfim, uma opinião, um sentimento com respeito a um fenômeno ou a um acontecimento (AUMONT, 1994, p.156).

Um aspecto importante do enquadramento refere-se ao seu valor conotativo:

Tudo o que nas imagens narrativas lhe faz traduzir uma visão subjetiva, "focalizada"; mais amplamente, a tudo o que faz com que um enquadramento traduza um julgamento sobre o que é representado, ao valorizá-lo, ao desvalorizá-lo, ao atrair a atenção para um detalhe no primeiro plano etc. (AUMONT, 1994, p.156).

Arlindo Machado complementa esse raciocínio ao falar do recorte do quadro e alusão ao extraquadro, afirmando que:

Toda visão pictórica, mesmo a mais "realista" ou a mais ingênua, é sempre um processo classificatório, que joga nas trevas da invisibilidade extraquadro tudo aquilo que não convém aos interesses da enunciação e que, inversamente, traz à luz da cena o detalhe que se quer privilegiar (MACHADO, 1984 p.76).

Dentro do campo dos estudos da Comunicação, considerou-se o conceito de agenda-setting. Segundo Wolf, o público dá importância a acontecimentos enfatizados pelos meios de comunicação de massa. $\mathrm{O}$ autor explica que a mídia coloca na ordem do dia os assuntos, dando importância, salientando sua centralidade, assim: "as notícias são enquadradas em temas, a mídia fornece categorias nas quais o receptor situa as matérias de modo significativo" (WOLF, 2008, p.145). Outro aspecto da agenda é o que o autor chama de agenda intrapessoal: relevância pessoal dada pelo individuo e agenda interpessoal: temas sobre os quais o individuo discute com outros dentro de uma rede de relações e de comunicação. É importante salientar que a agenda inclui além dos fatos o tratamento dado a estes fatos (CHARAUDEAU, 2006, p.42-43). Que nesta pesquisa podemos analisar não somente o Sertão, mas o olhar sobre esse Sertão. 


\section{A representação do Sertão na Agência Globo ${ }^{1}$}

\section{Figura 1}
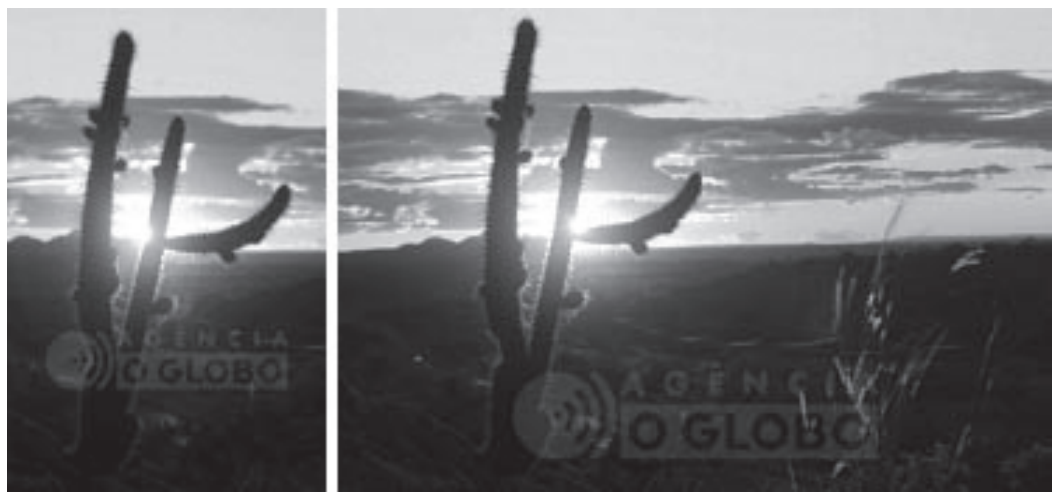

A primeira galeria é a da Agência Globo, o local é o Sertão Central de Pernambuco, com a legenda: "Na Caatinga do Nordeste só restam $30 \%$ da vegetação nativa". O texto da legenda fala de meio ambiente, de Caatinga, de vegetação perdida. A imagem mostra uma temperatura de cor bem quente. A imagem analisada ilustra um pôr do sol alaranjado, com tons de amarelos e vermelhos e uma silhueta marrom. A silhueta é formada por um cactos e por uma paisagem longínqua em segundo plano sem muitos detalhes. $\mathrm{O}$ item que se destaca nessa imagem são o cactos como elemento principal, indicando uma vegetação que suporta a falta de água, mas a legenda reforça a falta de água no Sertão ao afirmar que esta vegetação está desaparecendo, nem eles estão suportando. Tecnologia é um item inexistente na imagem. Evidenciando na prática o que Albuquerque Junior teoriza ao afirmar que "A relação entre o Sertão e a civilização é sempre encarada como excludente" (ALBUQUERQUE JÚNIOR, 2001 p.54).

${ }^{1}$ Galeria da Agência Globo de 25.04.2006, foto: Hans Von Manteuffel. Local Sertão Central. 
Figura $2^{2}$

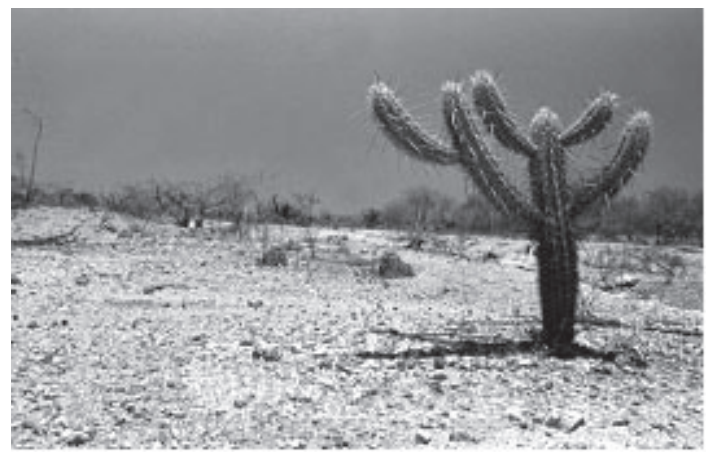

A legenda diz: "Solidão. O desmatamento desordenado na região de Solidão no Sertão do Pajeú contribui para o aumento da desertificação". A fotografia de um cacto solitário em terra seca traz na legenda os termos ‘solidão' e 'desertifi-

cação'. Solidão é o nome de uma cidade e aqui aparece como um jogo de palavras, a cidade referenciada não aparece na imagem retratada, parece a foto de uma área rural, que talvez nem seja longínqua e que a capacidade técnica da fotografia de fazer um recorte permitiu dar a ideia do arquétipo vegetativo do que seria o Sertão, a terra seca esbranquiçada, o cactos como único sobrevivente à seca, o céu azul sem uma nuvem que indica a chuva por vir. Novamente a tecnologia se torna inexistente, parece um ambiente inabitável devido à aridez territorial.

Figura $3^{3}$

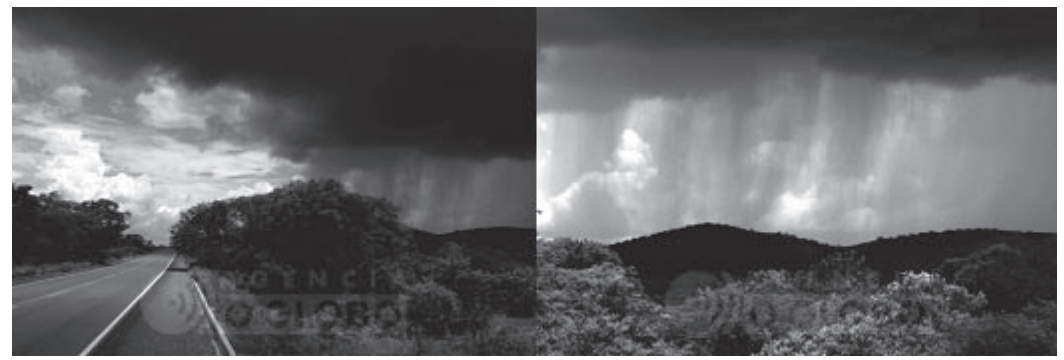

${ }^{2}$ Galeria Agência Globo. Fotógrafo: Josenildo Tenório. Local: Sertão do Pajeú. Data: 11.10 .2001

${ }^{3}$ Galeria Agência Globo. Foto: Gustavo Stephan. Local: Sertão do Ceará. Data: 11.05.2006 
A legenda da foto diz o seguinte: "Exclusiva. Chuva no Sertão do Ceará". Estas duas fotos estão dentro da galeria da Agência Globo e são as únicas que possuem um olhar diferenciado no que se refere às cores e à vegetação. A primeira imagem possui uma estrada asfaltada, provavelmente uma BR, onde não passa nenhum carro, a segunda imagem mostra montanhas e vegetação aparentemente intocada. São duas situações bucólicas, sem presença humana. Verdes, azuis e cinzas predominam. Não há referências à presença de tecnologias.

O céu carregado evidencia chuvas, assim como a vegetação verde e abundante. A estrada entra como elemento indicativo de comunicação daquele local com outras regiões. No entanto, a legenda remete à mesma preocupação das outras fotografias: a seca. $\mathrm{O}$ texto mostra que trata-se de um grande acontecimento o fato de estar chovendo no Sertão do Ceará com a palavra 'Exclusiva'. A imagem não é de seca, mas o texto se refere à seca. "O texto sobrecarrega a imagem, confere-lhe uma cultura" (BARTHES, 2009, p.21). Nesta fotografia, a legenda diz qual a mensagem sobre o sertão que quer ser mostrada.

Assim, concordamos com Aumont (1994, p.156) que esse enquadramento é uma escolha. A galeria pública da Agência globo possui somete cinco imagens que se referem ao Sertão e todas essas imagens discutem a seca, nas imagens e nas legendas. É o único ponto de vista sobre a região. Nenhuma imagem sobre a região mostrada trouxe outros aspectos, como é o caso do Aeródromo, Agência do Trabalho, Universidade de Pernambuco (Estadual), polo produtor de artesanato (ADDIPER, 2010a). Lavouras de subsistência, algodão, cana-de-açúcar e fruticultura, turismo ecológico, grupos folclóricos ou feiras gastronômicas (FÉRIAS TURISMO, 2010). Observamos um olhar único sobre a região. 


\section{A representação do Sertão no jornal O Globo: Seca em Alagoas}

Figura $4^{4}$

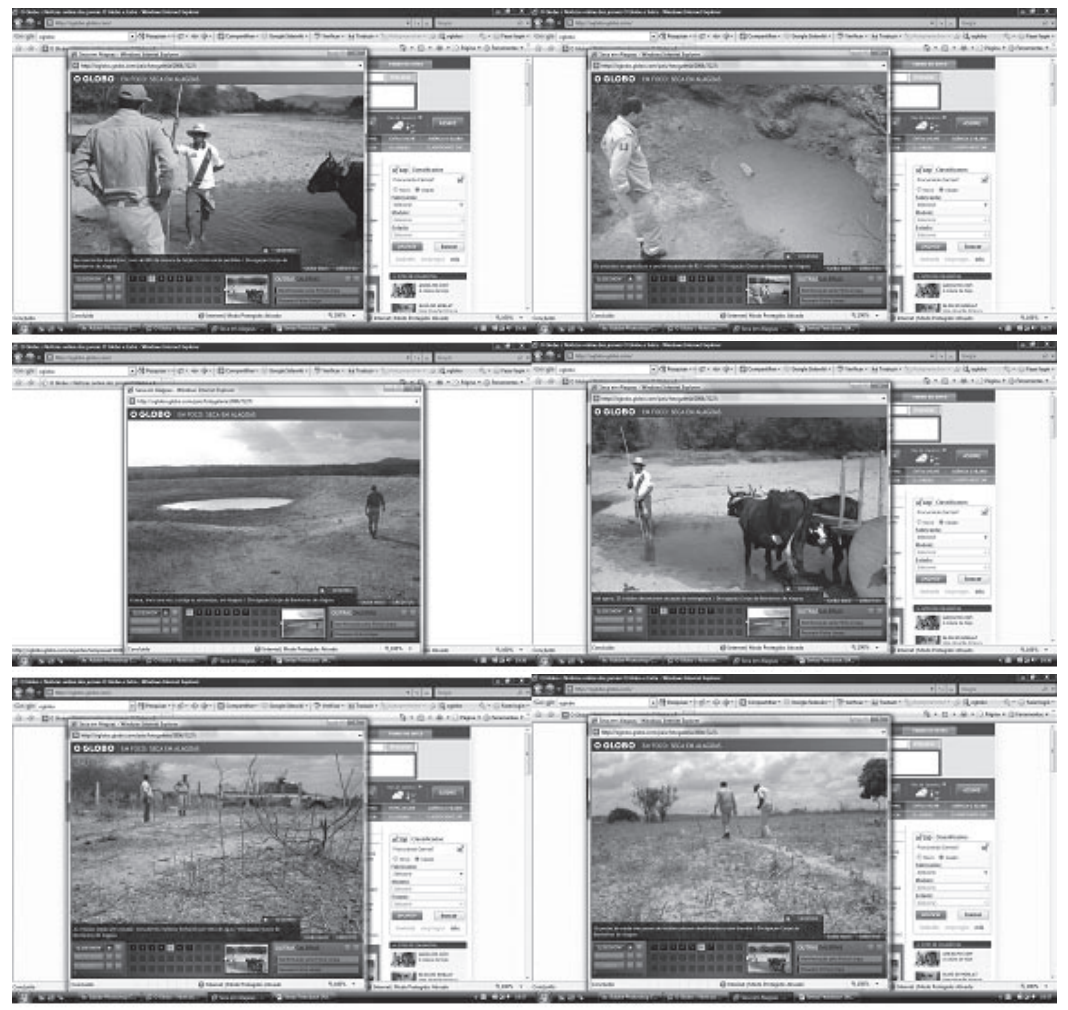

A galeria Seca em Alagoas é feita por fotos do corpo de bombeiros em 2008. São sete imagens com baixa resolução e uma nitidez comprometida provavelmente feita com máquina compacta simples ou celular. A fotogaleria começa com a frase: "a seca mais uma vez castiga os sertanejos”. Esta galeria traz elementos para reafirmar o assunto principal que está no título de todas as fotos: a seca. As imagens podem servir para afirmar um ponto de vista sobre a região ou a realidade. Aumont (1994, p.156) diz que o enquadramento é a materialização de um ponto de vista, percebe-se que o ponto de vista até agora é a seca, que explica o Sertão.

${ }^{4}$ Todas as fotos da galeria são do Corpo de Bombeiros. 
A imagem que inicia a galeria possui três elementos principais: a terra seca e sem vegetação, uma poça de água pequena e um homem do corpo de bombeiros supostamente indo em direção à água. As legendas dizem: "Até agora, 25 cidades detectaram situação de emergência/Divulgação/Corpo de Bombeiros". "Na maioria dos municícipios, mais de $80 \%$ da lavoura de feijão e milho estão perdidas". "Os prejuízos na agricultura e pecuária passam de $\mathrm{R} \$$ 1 milhão"; "Os postos de saúde não param de receber pessoas desidratadas e com diarreia"; "As crianças estão sem estudar; consultórios médicos fecharam por falta de água"; "As cidades esperam agora ajuda do governo federal, com caminhões-pipa".

A legenda fala em lavouras de milho e feijão que não aparecem nas imagens. Fala em agricultura e pecuária, mas não mostra nas imagens nenhuma dessas coisas, mesmo as legendas citando, as imagens não mostram médico ou crianças nas escolas, ou sequer escolas fechadas.

Observamos a categoria de análise Arquétipo de vegetação onde se observa uma terra seca, um espaço de água razo, carroça rudimentar de transporte, região desabitada. A última imagem que aparece nessa galeria mostra três pessoas pegando água de um poço, dois bois, árvores e uma casa.

\section{Figura 5}

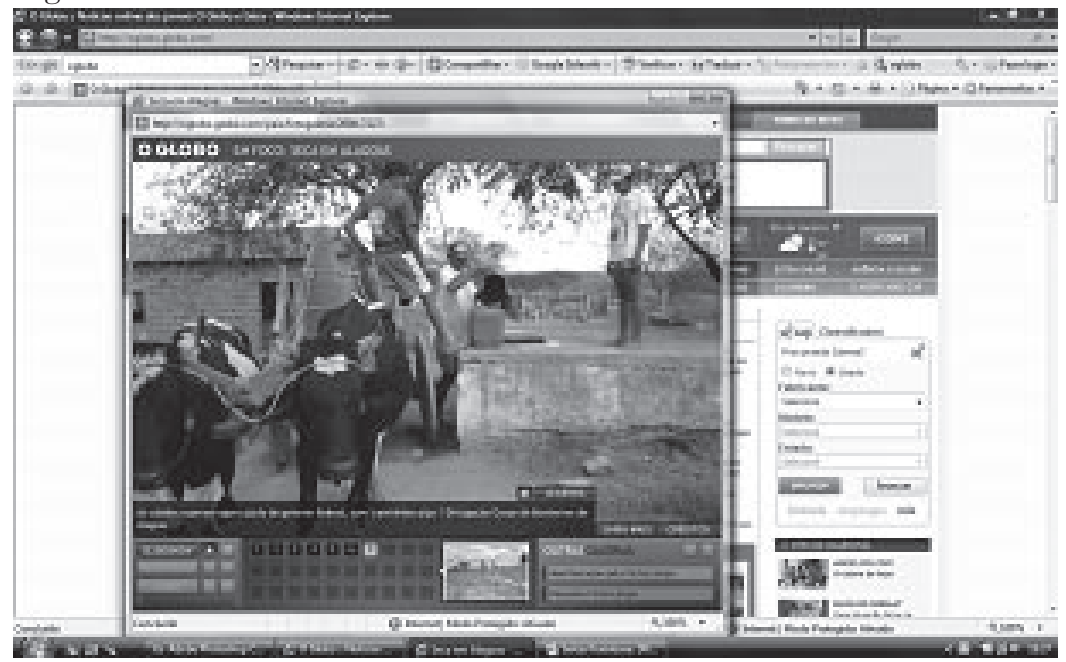


Não aparece o corpo de bombeiros, mas elementos que registram que a região é habitada, as pessoas não possuem aspectos que indiquem fraqueza, desidratação, desnutrição ou outros elementos que as legendas anteriores mostraram. $\mathrm{O}$ sistema de transporte é rudimentar, o chão demonstra que não se trata de uma rua, mas de um ambiente rural e observa-se que a região possui uma casa, os animais, o poço e as pessoas. O texto relacionado às fotos não indicam onde foram feitas essas imagens, somente há informação de que se trata do Sertão de Alagoas.

\section{Quinta-Feira Santa pelo mundo}

Figura $6^{5}$

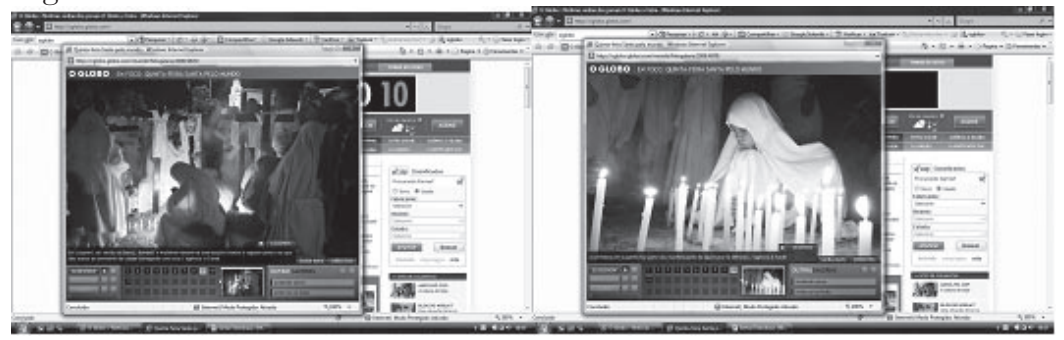

Desta galeria se analisa, conforme estabelecido na metodologia e na definição do corpus, as duas imagens feitas no Sertão da Bahia da Agencia A Tarde. Em ambas as pessoas fazem um ritual carregando uma cruz e vestidas de lençóis brancos. $\bigcirc$ texto que acompanha a primeira foto diz o seguinte: "Em Juazeiro, no Sertão da Bahia, homens e mulheres vestem-se com lençóis brancos e seguem pelas ruas que dão acesso ao cemitério da cidade carregando uma cruz"; a segunda legenda diz que: "A cerimônia em Juazeiro faz parte das manifestações da Quaresma há 200 anos". Diferentemente de todas as outras imagens analisadas anteriormente, estas fotografias são noturnas, com pouca luz, sem dar nenhuma informação sobre elementos vegetativos ou qualquer relação no texto ou na imagem no que diz respeito à seca. No entanto, estas duas fotografias mostram outros aspectos arquetípicos do sertanejo que é a tradição e a religiosidade. Uma religiosidade vista como

5 Fotos: Agência A Tarde. 
forma de resistência às condições impostas pela aridez do meio. Imagem disseminada em Os Sertões, no qual Euclides da Cunha diz que no Sertão existe uma insurreição da terra contra o homem e, para enfrentar esta batalha, Cunha (1901, p.134) diz que "A princípio este reza, olhos postos na altura. $\mathrm{O}$ seu primeiro amparo é a fé religiosa. Sobraçando os santos milagreiros, cruzes alçadas, andores erguidos, bandeiras do Divino ruflando".

Barthes (2009, p.23) afirma que "a leitura da fotografia depende do 'saber' do leitor"; o conhecimento das descrições sobre o povo sertanejo feitas por Euclides da Cunha em Os Sertões mostram como essas imagens podem entrar em uma categoria arquetípica de pessoas, essa representação social tem sido construída na história do país desde que esse primeiro jornalista fala sobre a região. É indiscutível a importância dada à religiosidade e ao sagrado na região, no entanto o pitoresco foi enfatizado, nas imagens de outros locais que não são o Sertão, observam-se imagens de igrejas, não são imagens inventadas, mas seguem um modelo de representação.

\section{Galeria Seca no Nordeste}

Figura $7^{6}$
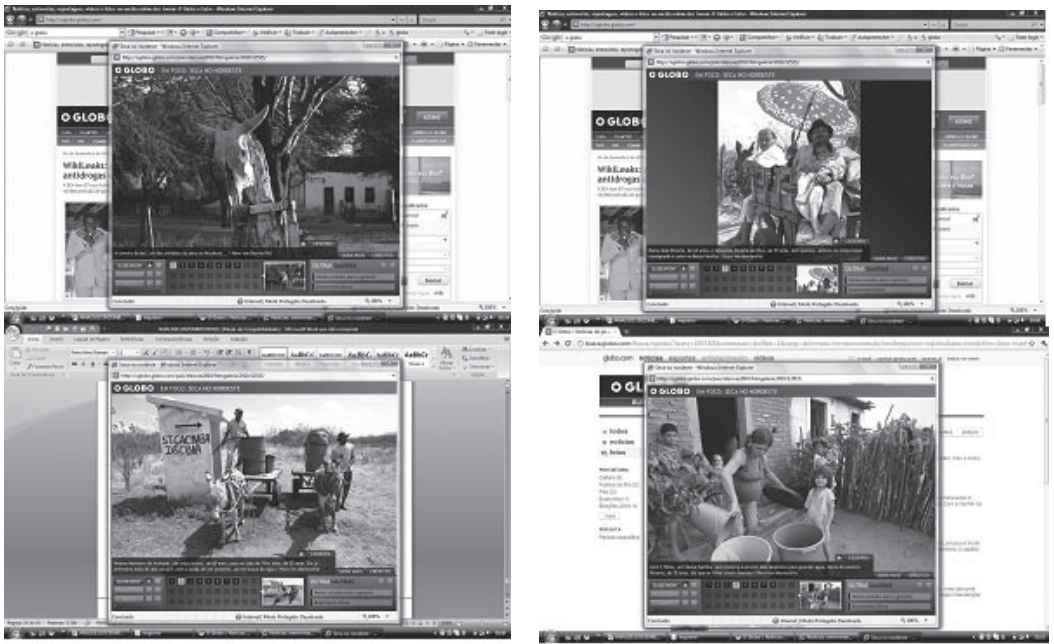

${ }^{6}$ Todas as fotos da galeria são de Hans Von Manteuffel. 
Esta galeria que retrata o sofrimento das populações do Nordeste ainda com a seca, publicada um mês antes das eleições presidenciais, o que indica motivações políticas do jornal $O$ Globo. Com a legenda: "A caveira do boi, um dos símbolos da seca no Nordeste"; temos na imagem e no texto um objeto arquetípico da seca no Sertão que como afirma Roland Barthes: "o homem adora os signos e adora-os de preferência claros" (BARTHES, 2009 , p.24). A caveira em primeiro plano deixa todos os outros elementos na foto a ela subjugados. A caveira foi o ponto de vista do fotógrafo, "Um local, real ou imaginário, a partir do qual uma cena é olhada" (AUMONT, 1994, p.156).

A segunda imagem apresenta duas pessoas enchendo cacimbas de água, a frase que acompanha diz o seguinte: "Heleno Monteiro de Andrade (de calça jeans), de 60 anos, posa ao lado do filho João, de 22 anos. Ele já enfrentou mais de dez secas, com a ajuda de um jumento, sai em busca de água”. O chão é de terra batida e reflete um sol de meio dia, A hora mais quente do dia o que deixa a luz forte e dura e o chão aceso, os dois utilizam jumentos e carroças como meios de transporte, a vegetação é seca e o céu azul que possui nuvens espaças ao fundo. Essa imagem registra a falta de água com todos os elementos, o chão está seco, a vegetação está seca, a hora do sol mostra que está quente e as pessoas estão precisando de água. Na legenda aparece que a localidade já enfrentou mais de dez secas. O texto evidencia a seca no Nordeste, título da galeria de imagens. Aumont (1995, p.207) explica que além de sua relação mimética mais ou menos acentuada com o real, a imagem veicula, de forma codificada, o saber sobre o real. Olhar pode ser direcionado por meio do recorte do enquadramento, o horário do registro, o local escolhido etc.

A legenda da imagem seguinte diz: "Maria José Pereira, de 63 anos, e Sebastião Pereira da Silva de 59 anos, tem queixas: débitos no empréstimo consignado e corte no Bolsa Família”. Registra uma família humilde, sendo transportada por uma carroça, tudo indica que a seca os deixou endividados. Não existem muitas explicações, somente informações soltas. O corte do Bolsa Família é um dado de crítica política ao PT. O leitor da imagem observa a vegetação seca, a charrete, a sombrinha que protege da quentura do sol e 
esses dados visuais serão somados à informação de "corte do Bolsa Família", essas informações trazem uma realidade para a imagem considerando que os pontos que são fixados no momento da percepção da foto serão somados aos dados da legenda.

Uma outra imagem possui a legenda: "Com 7 filhos, sem Bolsa Família, sem cisterna e só com depósitos para guardar água, Maria do Socorro Pereira, de 35 anos, diz que os filhos vivem doentes". A imagem mostra crianças, uma mulher grávida, cerca rudimentar, chão batido e um balde derramando bem pouquinha água. Na legenda a reclamação de que a falta de água traz doenças e dá a entender a omissão dos poderes públicos. A seguinte imagem mostra crianças, o texto diz que não existe cisterna e diz também que falta Bolsa Família, vários dados da legenda não estão aparecendo na fotografia. A água é um elemento presente para que a linha da reportagem que fala sobre Seca no Nordeste não perca o foco, e o fio de água que cai no balde indica escassez, a legenda deixa de trazer informação sobre a realidade da família mostrada. Uma diferença das outras imagens é a cerca mostrando uma vizinha na casa ao lado indicando que se trata de uma região habitada por pessoas e não somente de cactos.

\section{Figura 8}

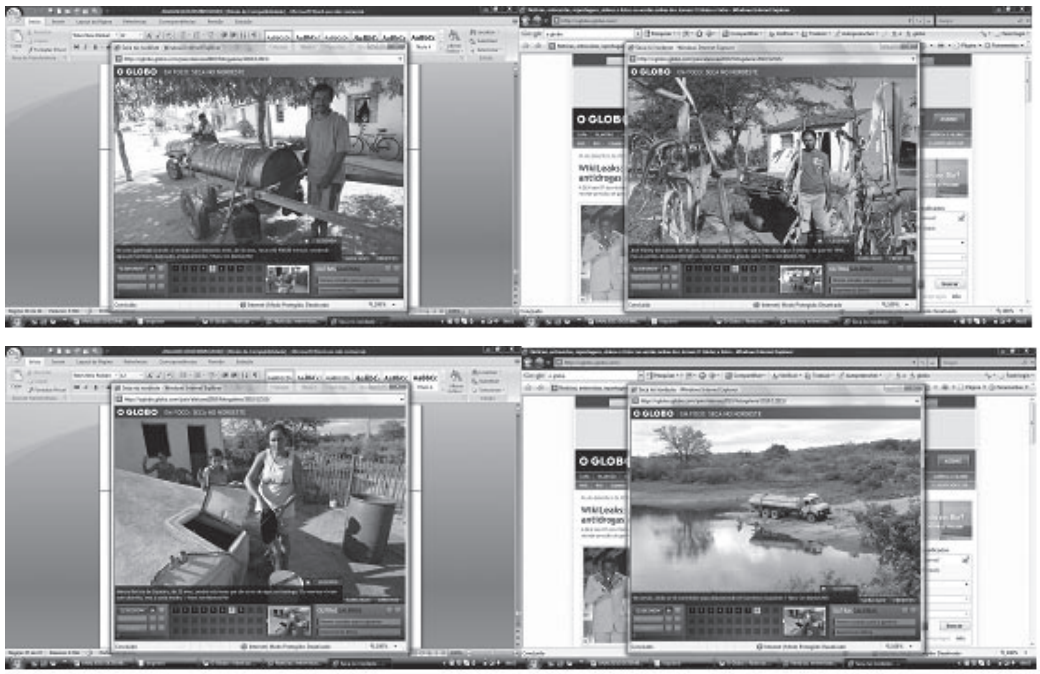


A fotografia seguinte mostra um homem carregando um tonel pequeno de água e feliz por que a seca traz renda. A legenda diz: "No sitio Queimada Grande, o lavrador Luis Sebastião Alves, de 36 anos, fatura $\mathrm{R} \$ 900,00$ mensais vendendo água em tambores duplicados artesanalmente". Nessa imagem aparece a ideia de cidade, é possível ver três casas, uma bicicleta, outro homem com tonel, parece uma região mais habitada, não se sabe exatamente de que local se trata. A imagem seguinte traz uma plantação bem seca, uma casa ao fundo, céu azul e a legenda: "José Vlaney dos Santos, de 36 anos, no sítio Tanque. Ele diz que a vida dos sogros é melhor do que em 1998, mas as perdas de lavoura foram as mesmas da última grande seca". A imagem arquetípica da seca é vista nas plantas secas e mortas, indica falta de transporte e um poste que indica que existe iluminação elétrica na localidade. A imagem seguinte diz: "Márcia Batista de Siqueira, de 32 anos, perdia três horas por dia atrás de água na caatinga: os meninos viviam com diarreia, mas a coisa mudou”. A imagem registra uma caixa de água e a dona da casa e personagem da matéria derramando água que tirou em abundância. Mostra que se trata de um sítio, e de um local com água suficiente que tem proporcionado saúde para as pessoas, ou seja, saneamento básico, água, higiene, segurança alimentar, qualidade de vida. A última imagem desta galeria diz o seguinte: "No Sertão, ainda se vê caminhões-pipa abastecendo em barreiros insalubres". Na imagem de uma região com água e um caminhão pipa próximo, a legenda indica que a água é insalubre. $\mathrm{O}$ que mostra uma denúncia sobre a ineficiência dos poderes públicos falta de fiscalização, assim como necessidade ainda existente em muitas cidades de saneamento básico o que afeta diretamente à higiene básica e saúde.

\section{Conclusão}

Observou-se como o jornal O Globo e a Agência Globo mostram o Sertão do Nordeste do Brasil em fotogalerias no seu site de informação. Encontraram-se imagens arquetípicas da vegetação do Sertão tais como cactos, folhas secas e nenhuma menção à agricultura extensiva ou familiar. Inicialmente não aparece qualquer 
tipo de flores ou frutos, somente aspectos de uma região seca. Destacou-se, entre as imagens arquetípicas do Sertão, a ossada de um animal morto na cerca de uma casa, associando a região à seca e, sobretudo, à morte.

Chama atenção o reducionismo temático nas imagens fotográficas, como se fosse possível tal uniformidade na identificação de uma região tão múltipla como é o Sertão do Nordeste. O sol, que quando aparece em destaque é quente, amarelo e indicando calor intenso. As únicas duas imagens que se diferenciam deste aspecto de forte temperatura mostram uma situação inusitada de chuvas, evidenciadas como um acontecimento tão esporádico que a notícia é dada como uma exclusiva do jornal $O$ Globo, sobrecarregando um sentido à imagem.

A água, que aparece como tema relacionado diretamente à seca, é mostrada como escassa, sempre por meio de depósitos como cacimbas e tonéis, registrando a dificuldade do acesso à ela. Aparecem também fotografias de água suja, caminhões pipas rudimentares e poças de água imprópria para o consumo. A escassez de água e a seca ainda se constituem nas imagens como a identificação do Sertão com a pobreza, subdesenvolvimento, miséria. As pessoas que apareceram nas imagens utilizam transporte rudimentar, estão à espera da ajuda do corpo de bombeiros e dos poderes públicos, sofrem com a falta de água e com a falta do Programa Bolsa Família. Não aparecem escolas, hospitais, não se faz menção a organizações sociais como cooperativas ou associações. $\mathrm{O}$ transporte que as imagens mostram são sempre as carroças, animais que levam charretes e ruas sem asfalto. Apenas em duas fotografias aparece uma estrada, em todas as outras o chão é de terra batida. A galeria que faz menção à religiosidade registra uma procissão, em um lugar isolado, umas cruzes, velas e lençóis, não aparecem nenhuma das igrejas nas praças.

$\mathrm{Na}$ problematização da pesquisa, foi apontada a existência de imagens estigmatizadas do Sertão do Nordeste, no entanto, a coleta e sistematização dos dados surpreenderam pela quantidade delas e a falta total de fotografias, nas galerias consultadas, que se contrapusessem àquela imagem da seca como única representação do Sertão. É possível detectar uma uniformidade no olhar, concor- 
damos com o que afirma Roland Barthes (1984, p.173): “uma das marcas de nosso mundo talvez seja essa inversão: vivemos segundo um imaginário generalizado".

A fotografia, assim como outras formas artísticas de representar a realidade, pode promover o estranhamento, trazendo à tona questões nunca antes discutidas, em vez de trazer à sociedade uma sucessão reducionista de imitações já vistas. "A informação é essencialmente uma questão de linguagem, e a linguagem não é transparente ao mundo, ela apresenta sua própria opacidade através da qual se constrói uma visão, um sentido particular do mundo" (CHARAUDEAU, 2006, p.19), assim a realidade do Sertão faz parte de uma construção em que elementos foram escolhidos dentro de um universo muito mais amplo, fazendo uso da característica essencial da fotografia que é a de ser polissêmica, possuir significados flutuantes dos quais uns são escolhidos em detrimento de outros (Barthes, 2009). Assim a imagem do Sertão, identificada nesta pesquisa, é um objeto que foi trabalhado, escolhido, composto, construído, tratado segundo normas profissionais, estéticas ou políticas.

Importante salientar que consideramos que faz parte do serviço prestado à sociedade pelos meios de comunicação de massa a função de questionar e fiscalizar o poder público e a desigualdade social, no entanto pode também contribuir para mostrar as vocações locais de cada região, cobrar a descentralização da gestão pública; formar parcerias entre o estado local e a sociedade civil, com adensamento das energias sociais; ter maior eficácia na implementação dos objetivos e das metas; assim como cobrar a inserção estrutural das mulheres rurais nas atividades produtivas e nas esferas de decisão; divulgar as possibilidades de que se crie uma maior autossuficiência e menos dependência de apoios externos.

Dessa forma, o jornalismo que não rompe com processos estereotipados perde a oportunidade de contribuir para o conhecimento real da região e, em última análise, do país. Parece que a realidade única escolhida para retratar o Sertão é o olhar que o sobrecarrega de um significado específico, o da seca, isso é a materialização do que diz Arlindo Machado (1984, p.76): 
Toda fotografia, seja qual for o referente que a motiva, é sempre um retângulo que recorta o visível. O primeiro papel da fotografia é selecionar e destacar um campo significante, limitá-lo pelas bordas do quadro, isolá-lo da zona circunvizinha que é a sua continuidade censurada.

A fotografia como notícia é capaz de mobilizar (PESAVENTO, 2008, p.106), trazer à tona a reflexão, questionar o que está estabelecido, no entanto o fotojornalismo no tema em pauta mostra um ciclo vicioso de imagens iguais, preso a uma memória social da representação fotográfica construída no senso comum que identifica nas imagens um Sertão, seco, quente, improdutivo, miserável, arcaico, um olhar real sobre a região, mas não o único, existem outros Sertões, outras discussões que não são trazidas a tona em nenhuma imagem, a seca parece ser o único tema, a categoria central na qual todos os questionamentos sobre o Sertão devem encaixar-se para ser mostrado nos jornais sem chocar ou frustrar o modelo pré-estabelecido pelo senso comum.

\section{Referências}

ABRIC, Jean-Claude. A abordagem estrutural das representações sociais. In: MOREIRA, Antonia S. P.; OLIVEIRA, Denize C.de. (Orgs.). Estudos interdisciplinares de representação social. Goiânia: AB, 1998. p.27-38. Sertão Central: ADDIPER, Disponível em : http://www.addiper.pe.gov.br/site/page. php?page_id=36. Acesso em: $26 \mathrm{dez} .2010$.

ALBUQUERQUE JÚNIOR, Durval Muniz de. A invenção do Nordeste e outras artes. Recife: FJN, ED. Massangana; São Paulo: Cortez, 2001.

ALEGRE, Maria Sylvia Porto. Reflexões sobre iconografia etnográfica: por uma hermenêutica visual. In: FELDMAN-BIANCO, Bela; MOREIRA LEITE, Mirian L. (Orgs.). Desafios da imagem: fotografia, iconografia e vídeo nas ciências sociais. Campinas: Papirus, 1998. p.75-112.

AUMONT, Jacques. A imagem. Campinas: Papirus, 1994.

BARTHES, Roland. A câmera clara: nota sobre a fotografia. Rio de Janeiro: Nova Fronteira, 1984. 
BARTHES, Roland. O óbvio e o obtuso. Lisboa: Biblioteca Nacional de Portugal, Edições 70, LDA, 2009.

CUNHA, Euclides da. Os sertões (1901). Rio de Janeiro: Record,1998.

CHARAUDEAU, Patrick. Discurso das mídias. São Paulo: Contexto, 2006.

DUBBOIS, Philippe. O ato fotográfico e outros ensaios. São Paulo: Papirus, 1993.

FÉRIAS TURISMO. Solidão - PE. Disponível em: http://www.ferias.tur.br/ informacoes/5461/solidao-pe.html. Acesso em: 11 jul. 2010.

INCLUSÃO produtiva e autossustentável no Sertão de Alagoas. Governo de Alagoas - Secretaria de Estado da Agricultura e Desenvolvimento Agrário. Maceió. Disponível em: http://www.agricultura.al.gov.br/sala-de-imprensa/ noticias/2010/outubro/inclusao-produtiva-e-autossustentavel-no-sertao-de-alagoas. Acesso em: 13 dez. 2010.

GUIA DAS CIDADES DIGITAIS. A união da tecnologia com a criatividade. [s.l.]. Disponível em: http://www.guiadascidadesdigitais.com.br/site/pagina/ tau-no-serto-cearense-une-tecnologia-e-criatividade. Acesso em: 06 jul. 2010.

KOSSOY, Boris. Realidades e ficções na trama fotográfica. São Paulo: Ateliê, 1999.

KUNCZIK, Michael. Conceitos de jornalismo: norte e sul: manual de Comunicação. Tradução Rafael Varela Jr. 2.ed. São Paulo: Editora da Universidade de São Paulo, 2001.

MACHADO, Arlindo. A ilusão especular. São Paulo: Brasiliense, 1984.

MINISTÉRIO DO DESENVOLVIMENTO AGRÁRIO - Secretaria de Agricultura Familiar - Comunidades. Brasília. Disponível em: http://comunidades. mda.gov.br/portal/saf. Acesso em: 02 out. 2009.

MINISTÉRIO DO DESENVOLVIMENTO AGRÁRIO. Território da Cidadania Inhamuns Crateús - CE. Disponível em http://www.territoriosdacidadania. gov.br/dotlrn/clubs/territoriosrurais/inhamunscratesce/one-community?page_ num $=0$. Acesso em: 13 nov. 2010.

MOSCOVICI, Serge. Representações sociais: investigações em psicologia social. Petrópolis: Vozes, 2009. 
SECA NO NORDESTE. O Globo, Rio de Janeiro, 03 set. 2010. Disponível em: http://oglobo.globo.com/pais/eleicoes2010/fotogaleria/2010/12515/. Acesso em: $26 \mathrm{dez} .2010$.

PESAVENTO, Sandra J. O mundo da Imagem: território da história cultural. In: . SANTOS, Nádia M.Weber, ROSSINI, Miriam de S.(Orgs.). Narrativas, imagens e praticas sociais: percursos em historia cultural. Porto Alegre: Asterisco, 2008. p. 99-122.

PREFEITURA DE SOLIDÃO. Solidão-PE. Disponível em: http://www.prefeiturasolidao.com.br/. Acesso em: 11 jul. 2010.

SÁ, Celso Pereira de. Núcleo central das representações sociais. Petrópolis: Vozes, 1996.

MP INVESTIGA "comemoração" no Orkut de tragédia no Nordeste. Terra. São Paulo, 09 set.2010. Disponível em : http://noticias.terra.com.br/brasil/ noticias/0,,OI4556090-EI5030,00-MPE + investiga + preconceito + contra + nord estinos + na+internet.html; Acesso 10 julho 2010

WOLF, Mauro. Teorias das comunicações de massa. São Paulo: Martins Fontes, 2008. 